Al-Uqud: Journal of Islamic Economics Volume 4 Issue 2, July 2020

E-ISSN 2548-3544, P-ISSN 2549-0850 DOI:10.26740/al-uqud.v4n2.p186-199

Accredited No. 28/E/KPT/2019

Page 186-199

\title{
The Synergy Model for Strengthening the Productivity of Indonesian Halal Industry
}

\author{
Ana Toni Roby Candra Yudha ${ }^{1 *}$, Nasif Sidquee Pauzi ${ }^{2}$, Rafidah binti Mohd Azli ${ }^{3}$ \\ ${ }^{1}$ Department of Islamic Economics, Faculty of Islamic Economics and Business, \\ Universitas Islam Negeri Sunan Ampel, Indonesia \\ Jalan A. Yani, Surabaya 60237, Indonesia \\ ${ }^{2}$ Academy of Contemporary Islamic Studies (ACIS), UniversitiTeknologi MARA (UiTM) \\ Negeri Sembilan Branch, 70300, Seremban, Negeri Sembilan, Malaysia \\ ${ }^{3}$ Academy of Contemporary Islamic Studies (ACIS), UniversitiTeknologi MARA (UiTM), \\ Negeri Sembilan Branch, 72000, Kuala Pilah, Negeri Sembilan, Malaysia.
}

\begin{abstract}
Halal industry has become a new commodity that is favoured by all countries around the world, including Indonesia. The main challenge of halal industry development is strengthening its position as a producer in the global halal industry market. This study aims to investigate the number of policy proposals relating to strengthening the productivity of the halal industry in Indonesia and then develop a model of synergy over this matter. This study uses a qualitative study approach, with literature review, observation and interview as data collection methods. The results obtained from this study include several things, specifically; the focus of economic development in Indonesia is fundamentally still focused on the processed industry, which incidentally is dominated by imported raw materials. Based on the results of the analysis of the discussion, the implications of these studies is providing input for authorities such as BPJH, MUI and related ministries to adjust the regulation that address the main business challenge of halal industry. Besides, the government should give special authority to state-owned and private sharia banks to finance the halal industries and agricultural to support their sustainable development.
\end{abstract}

Keywords: Synergy; Productivity; Halal Industry; BPJH; MUI.

Paper type: Research paper

*Corresponding author: anatoniroby@uinsby.ac.id

Received: March 03, 2020; Accepted: April 12, 2020; Available online: April 27, 2020; Published regularly: July 2020

Cite this document: Yudha, A. T. R. C., Pauzi, N. S., Mohd Azli, R. B. (2020). The Synergy Model for Strengthening the Productivity of Indonesian Halal Industry. Al-Uqud: Journal of Islamic Economics, 4(2), 186-199. doi: http://dx.doi.org/10.26740/aluqud.v4n2.p186-199

Copyright () 2020, Al-Uqud: Journal of Islamic Economics

http://journal.unesa.ac.id/index.php/jie 
Ana Toni Roby Candra Yudha, Nasif Sidquee Pauzi, Rafidah binti Mohd

Azli: The Synergy Model for Strengthening the Productivity of Indonesian Halal Industry

\begin{abstract}
Abstrak: Industri halal telah menjadi komoditas baru yang disukai oleh semua negara di dunia, termasuk Indonesia. Tantangan utama pengembangan industri halal adalah memperkuat posisinya sebagai produsen di pasar industri halal global. Penelitian ini bertujuan untuk menyelidiki sejumlah proposal kebijakan yang berkaitan dengan penguatan produktivitas industri halal di Indonesia dan kemudian mengembangkan model sinergi dalam hal ini. Penelitian ini menggunakan pendekatan studi kualitatif, dengan tinjauan literatur, observasi dan wawancara sebagai metode pengumpulan data. Hasil yang diperoleh dari penelitian ini meliputi beberapa hal, khususnya; fokus pembangunan ekonomi di Indonesia pada dasarnya masih terfokus pada industri olahan, yang notabene didominasi oleh bahan baku impor. Berdasarkan hasil analisis diskusi, implikasi dari studi ini adalah memberikan masukan bagi otoritas seperti BPJH, MUI dan kementerian terkait untuk menyesuaikan peraturan yang menangani tantangan bisnis utama industri halal. Selain itu, pemerintah harus memberikan otoritas khusus kepada bank-bank syariah milik negara dan swasta untuk membiayai industri halal dan pertanian untuk mendukung pembangunan berkelanjutan mereka.
\end{abstract}

Kata kunci: Sinergi; Produktivitas; Industri halal; BPJH; MUI.

\title{
INTRODUCTION
}

Halal has become a parameter and characteristic for the world that wants to determine the quality of the products and services it produces, and halal products can be accepted by all groups both Muslim and non-Muslim (Murti, 2017; Battour, Hakimian, \& Ismail, 2018; Salman, 2018). Not a few figures, institutions and even the world began to realize and appreciate the emergence of unique and universal phenomena that are then praised by all countries in all parts of the world. A halal phenomenon in the world is not only struggling in the discussion of food alone (Hegnes, 2019). The phenomenon of halal industry in the world has also spread to several countries in Southeast Asia, including Indonesia (Tieman, 2019; Wingett \& Turnbull, 2020). At least the variants of goods and services that have become the object of discussion at the international business level are food and beverages, halal tourism (Aprizal, Mirdhayati, \& Yendraliza, 2019), Muslim fashion and halal fashion (Ishak et al., 2016), halal media and recreation, Islamic banking (Oseni, Ali, \& de Anca, 2019), Islamic microfinance (Alam, Gupta, \& Shanmugam, 2017), halal pharmaceuticals (Kulsum, Adawiyah, Shofwaturrohmani, \& Nurjanah, 2019), the handling of halal certification (Muhamed et al., 2019) and cosmetics (Swidi et al., 2010), as well as renewable energy (Chitrakorn, 2015).

The position of halal goods and services purchases throughout the world in 2017 amounted to 1,303 billion USD or equivalent to around Rp.18,242 trillion (Reuters, 2018), with an increase occurring in 2023 with a value of 1,862 billion USD or equivalent to Rp.26,068 trillion or an increase of 6.1\% (Paul Cochrane et al., 2018). Whereas Indonesia specifically turns out to be included in the category of the Top Muslim commodity business (Yudha et al., 2020) or Food Expenditure country and ranks unmitigated (Kamaruddin, Iberahim, \& Shabudin, 2012), which is the first rank in terms of halal goods and (Takeshita, 2019) services shopping (Afifi et al., 2014), with a value of 170 billion USD or equivalent to Rp2,380 trillion (assuming an exchange rate of 1 USD $=$ Rp.14,000). This happens because Indonesia is a country with the largest Muslim population in the world (Shaari, 
2018), so it has the potential to become a destination country for halal exports of goods and services, they also have a willingness to pay for halal products which are quite high (Kamaruddin, Iberahim, \& Shabudin, 2012). Apart from being the first rank in top Muslim food expenditure (Afifi et al., 2014), Indonesia also ranks fifth in top Muslim travel expenditure (Thomson Reuters and Dinar Standard, 2018), third in top Muslim apparel expenditure, fifth in top Muslim media expenditure, and sixth in top Muslim pharmaceutical expenditure. However, there are a few other unique phenomena related to the halal food and beverage industry (Wingett \& Turnbull, 2020), namely, developed countries that have fewer Muslim populations have a high market share for halal food (Afifi et al., 2014).

This becomes a dilemma; on one side, it is evident that Indonesia will increase GDP from consumption variables in the aggregate and increase willingness to pay (Kamaruddin, Iberahim, \& Shabudin, 2012). However, on the other hand, the consumptive characteristics inherent in Indonesian Muslim society will be a deduction from the country's foreign exchange (Tan, 2017) because the state income will not be productive in the country (Ali, Xiaoling, Sherwani, \& Ali, 2017); moreover, the data as explained in the previous section states that Indonesia ranks first as the country with the highest spending and uses of halal goods and services (Naeem \& Ayyub, 2019). Therefore, this must be addressed with a mindset change and behaviour that is initially consumptive to productive (Wahyu \& Sheikh, 2016). This becomes an opportunity as well as a strength to improve the quality of Indonesia's macro economy by producing halal goods and services (Haleem \& Khan, 2017), which at least able to meet domestic market demand (Antara, Musa, \& Hassan, 2016).

Islamic bank (Ryandono, 2020), and macro conditions populated by the consumption of halal goods and services (Tieman, 2019), must be addressed with a strategic approach (Rahman, 2017), and indeed the Indonesian people should consume halal and hygienic products (Mohd Nawawi et al., 2019). There are strategic efforts in several countries in developing superior commodities in their countries, Qatar, for example. At the end of March 2019, Qatar launched an Energy Bank with a capital of 10 billion USD or the equivalent of Rp142 trillion (Thomson Reuters and Dinar Standard, 2018). The purpose of the bank's establishment was to develop business and strengthen Qatar's economic fundamentals supported by gas and oil. Regarding such phenomena and loopholes, Islamic banks can develop policies by adopting a new business approach, in addition to the intermediation and social functions.

Islamic banking in Indonesia must have an initiative and specialize in business, especially businesses that support national economic fundamentals (Davies, 2015). Islamic banks in Indonesia may strive to encourage the manufacturing sector or the processed industrial sector which is an element of strengthening the industrial sector and halal certification (Ab Talib, Ai Chin, \& Fischer, 2017) because it is proven by the existence of halal certification certifiers (Anwar, Fahrullah, \& Ridlwan, 2018), that will increase perceptions and preferences for certain products (Anwar, Fahrullah, \& Ridlwan, 2017), or by establishing a bank that focused on agriculture that aims to support the provision of food and palm oil. It is because the halal industry is a very potential market in the 
Ana Toni Roby Candra Yudha, Nasif Sidquee Pauzi, Rafidah binti Mohd

Azli: The Synergy Model for Strengthening the Productivity of Indonesian Halal Industry

future that has not been fully explored So, with such specialization, it is expected that later it can support the development and growth of Indonesia's economic growth in a sustainable manner (Sustainable Development Goal's or SDG's). Another example is Malaysia. The country had a Halal Master Plan in 2008 with a vision of making Malaysia in 2020 a halal centre for the world and halal as a new source of Malaysia's economy. Malaysia is also a leader in the management of sharia finance, sharia insurance or takaful (Habibi \& Yudha, 2017), and other real aspects. Then this was followed up by the process of establishing institutions and supporting activities, such as Halal Development Corporation (HDC), several halal research centres at the university level to the annual activities of the Malaysia International Halal Showcase (MIHAS) (Muhamed et al., 2019). Indonesia's attitude should be rushed, because it already has a strong foundation that is the Muslim population as much as 88 percent to become a supporting factor of the halal industry (Tieman, 2011), not only in the regional scope but also at the global level.

In the meantime, to ensure that the halal industry continues and remains intact, (Hong et al., 2019) argued the requirement of comprehensive cooperation among government, industry (Yudha \& Dusturiya, 2018), Islamic entrepreneurial (Zaki et al., 2020), academy and research centre to set realistic and effective halal industry development approach. It is recommended that comprehensive government support should be reinforced under one grand value of 'cooperation' that covers optimal approach, diversity, efficiency and harmony (Park \& Jamaludin, $\underline{2018)}$.

$\mathrm{He}$ also suggested that various representatives of stakeholders including government agencies keep professionalism (Toni, 2020), and work together to conduct direct discussion regarding the development of the halal industry from supply chain to administration level (Tan, 2017). This type of discussion can be considered as integrated opinion sharing, which could highlight the high and actual demands of industry players.

The existence of conditions and demands, as reviewed in the previous section, is enough to be a driving factor for being assertive in developing a strategy to strengthen the halal industry. The step to take this strategy cannot take place quickly, simply and a little sacrifice, but on the contrary is to proceed, planned and sacrificed. Following this phenomenon, it is interesting to do a review of concepts and phenomena that are developing now to process and find effective strategies to strengthen the productivity of the halal industry in Indonesia.

\section{RESEARCH METHODS}

This study uses a qualitative approach. An approach that does not rely on numerical data and secondary data, but rather uses primary data in the form of interviews and field observations. The study of past works of literature, documents studies, passive observation and interviews with the Halal industry experts become the sources of the data. Document studies are the processes of collecting data derived from financial reports; opinion articles presented both online and offline, exposure to seminars and workshops, and interviewing practitioners whose expertise is relevant to the theme of the study raised this time. Passive observation is an activity of observing the phenomena that are developing today, especially phenomena related 
to the Islamic economy and halal industry that occur both globally, regionally and locally.

In other words, data sources of this paper are derived from the primary and secondary sources. The primary source is coming from the informant who directly expressed his opinion through seminar forums, workshops and talk shows. In this study, the informants referred to Ventje Rahardjo Soegiono and Sutan Emir Hidayat. Both are the Executive Management of the National Sharia Finance Committee. The other informants who provide data and information to supports this paper is Adiwarman A. Karim from Karim Consultant, Emil E. Dardak who is the Deputy Governor of East Java who gave the research materials in the same forum and 2019 Annual International Finance Conference in Surabaya. The secondary source of this study comes from the library studies and documents studies.

Data collection in this study is different from the quantitative approach. Data collection in this study uses three stages, namely pre-observation, informant interview, and triangulation. Pre-observation is carried out in order to obtain an initial overview of the substance of the problem in this study. Based on the results of observations that have been made, obtained reviews of experts from various backgrounds, such as from scholars, academics, practitioners, as well as representatives from government institutions such as Otoritas Jasa Keuangan (OJK) and Bank Indonesia (BI).

Then, the triangulation technique is carried out after the two previous stages have been completed. Triangulation is carried out to obtain valid and objective data, data received by all informants. The data submitted has 'slices' that are interrelated with one informant with another informant.

\section{RESULTS AND DISCUSSION}

In order to investigate the synergies of halal industry in Indonesia, this paper attempts to present the latest development of Halal environment happens in Indonesia. The discussion of literature has been divided into three (3) Sections: (1) Current observational efforts in Indonesia; (2) Indonesia's Global Halal Industry; (3) Current Strategies Developed in Indonesia.

\section{The Current Observational Efforts in Indonesia}

This section explains the current observational efforts. The phenomenon that occurs is the phenomenon of growing and internalizing the industrial revolution 4.0 and the development of halal industry business (Khasanah, Amalia, El Viera, \& Sawitri, 2019), which is run by some Muslim-populated countries and also a small part of developed countries.

At least these phenomena can be grouped and sequenced into one big idea that becomes a trend called global halal trends (Tieman \& Ghazali, 2012). Global halal trends are shown by several indicators, namely the existence of enormous market opportunities, there is a marked imbalance between the level of consumer demand and supply of producers, widespread literacy and internalization of the industrial revolution 4.0 (Satya, 2018), to all aspects of life and the development of literacy and economic socialization an Islamic perspective that is applied not only by majority populous countries such as Malaysia, Saudi Arabia, Qatar, Bahrain, 
Ana Toni Roby Candra Yudha, Nasif Sidquee Pauzi, Rafidah binti Mohd

Azli: The Synergy Model for Strengthening the Productivity of Indonesian Halal Industry

Egypt, Indonesia, and other similar countries, but is also favoured by non-Muslim majority countries such as Singapore, Britain, Canada, Thailand, and other similar countries (Thomson Reuters and Dinar Standard, 2018).

Each country seeks to identify the potential and opportunities, as well as the competitors' threats for its superior halal products. Because with these efforts at least every country gets a picture of the opportunities and prospects in utilizing, producing and marketing halal goods and services to other countries, both predominantly Muslim countries and Muslim minorities in all parts of the world.

\section{Indonesia's Global Halal Industry}

The global halal trend has become a necessity that must be experienced by every country, including Indonesia. Through global halal trends, all aspects have begun to make adjustments and use opportunities; these have begun to appear in the halal food and beverage industry, the Islamic finance and banking industry, halal fashion, sharia tourism and travel, as well as cosmetics and halal medicine which are increasingly being promoted and developed by countries that have field specifications.

The halal industry is currently becoming an interesting discussion at the global level. The global Muslim population, which accounts for around $24.1 \%$ of the world's population, or around 1.8 billion people, is proliferating, creating demand for halal products and services. According to the 2018/2019 Global Islamic Economy Report released by Thomson Reuters, global Muslim population expenditure on food and beverage products grew at a rate of $6.1 \%$ and is expected to reach USD 1.9 trillion in 2023, and clothing needs reaching USD 28 billion. In the same release, Indonesia is estimated to represent $13 \%$ of the global Muslim population in 2015 and is the country with the largest Muslim population in the world. In other words, Indonesia is a large and potential market for the halal industry, especially food and beverages. This does not yet calculate the potential of halal pharmacy and halal tourism which also continues to grow, including the potential of livestock, perennial, freshwater fisheries and marine.

Nevertheless, so far, Indonesia's position in the global halal industry arena has not been significant. Still, according to a Thomson Reuters release, Indonesia has not been included in the top 10 countries with the best performance in the halal food sector or halal pharmaceuticals and cosmetics, even losing to Brazil (ranked 3) and Australia (ranked 6) in the halal food sector and Singapore (ranked 3) in halal pharmacy and cosmetics, which these countries are not countries with a majority Muslim population. In other words, Indonesia, with a large Muslim population; however, an industry that not yet strong has the potential to only be consumers and viewers in their own country. The presence of the JPH Law is expected to strengthen Indonesia's position in working on such a sizeable halal industry 'economic cake'.

\section{Current Strategies Developed in Indonesia}

The targets and strategies developed by KomiteNasionalKeuanganSyariah (KNKS) and its partners must cover at least a few things. First, there is a synergy of government institutions in the concept of strengthening the halal industry, and until 
now, it has been running well, it needs further efforts to spawn several real agreements.

Second, the regulations that have been spawned by Badan Penyelenggara Jaminan Produk Halal (BPJPH) in the form of the Halal Product Guarantee Act (JPH) which was initiated on October 11, 2017, to be realized immediately because it provides legal certainty and will become legal protection in developing the halal industry. This expectation was high in the community, given the discourse of realization in October 2019 and can touch the MSME sector, where MSME is a source of real economic strength in Indonesia in particular. At least this is similar to the policies issued by the neighbouring country of Malaysia, which had already prepared a Halal Master Plan in 2008 with the financing of 1.35 percent of its GDP, as well as Qatar which built an Energy Bank with an initial capital of 100 million USD or equivalent with Rp.14 trillion to provide financing to all energy companies in the country and to make the energy sector supports the economic fundamentals of Qatar grow.

Third, the introduction of halal education since secondary school level in the form of vocational or vocational training, so that the vocational curriculum is expected to be able to provide insights and skills for the community to manage and contribute to the development of the halal industry going forward. The focus of vocational education, which should be carried out later, should prioritize and lead to the practice of sharia tourism and certainly be able to strengthen the entrepreneurial insights and mentality of the students, which are not just theoretical explanations.

Fourth, seek and authorize Islamic banks to finance all forms of financing that are feasible on all halal business lines in Indonesia as a mutual relationship because one side will facilitate aspects of the development of the halal industry which requires additional capital. On the other hand, Islamic banking, of course, has the opportunity to develop its assets and profits in line with the increase in national shares. Fifth, support all companies in Indonesia that are willing to produce halal goods by providing halal certification at a far more efficient cost.

The combination of the values mentioned above is a systematic effort to build and strengthen the halal industry in Indonesia. Indonesia as a country that has all the requirements to become a developed country should properly continue to strive with innovation, capture prospects and utilize all the resources available in the country both natural resources, human resources and technological resources.

Therefore, the halal industry in Indonesia can provide higher added value for consumers, and innovations that require research and development can continue. Based on the three major stages above, then in order to facilitate illustration and understanding, a figure of the model is arranged as shown below. 
Azli: The Synergy Model for Strengthening the Productivity of Indonesian Halal Industry

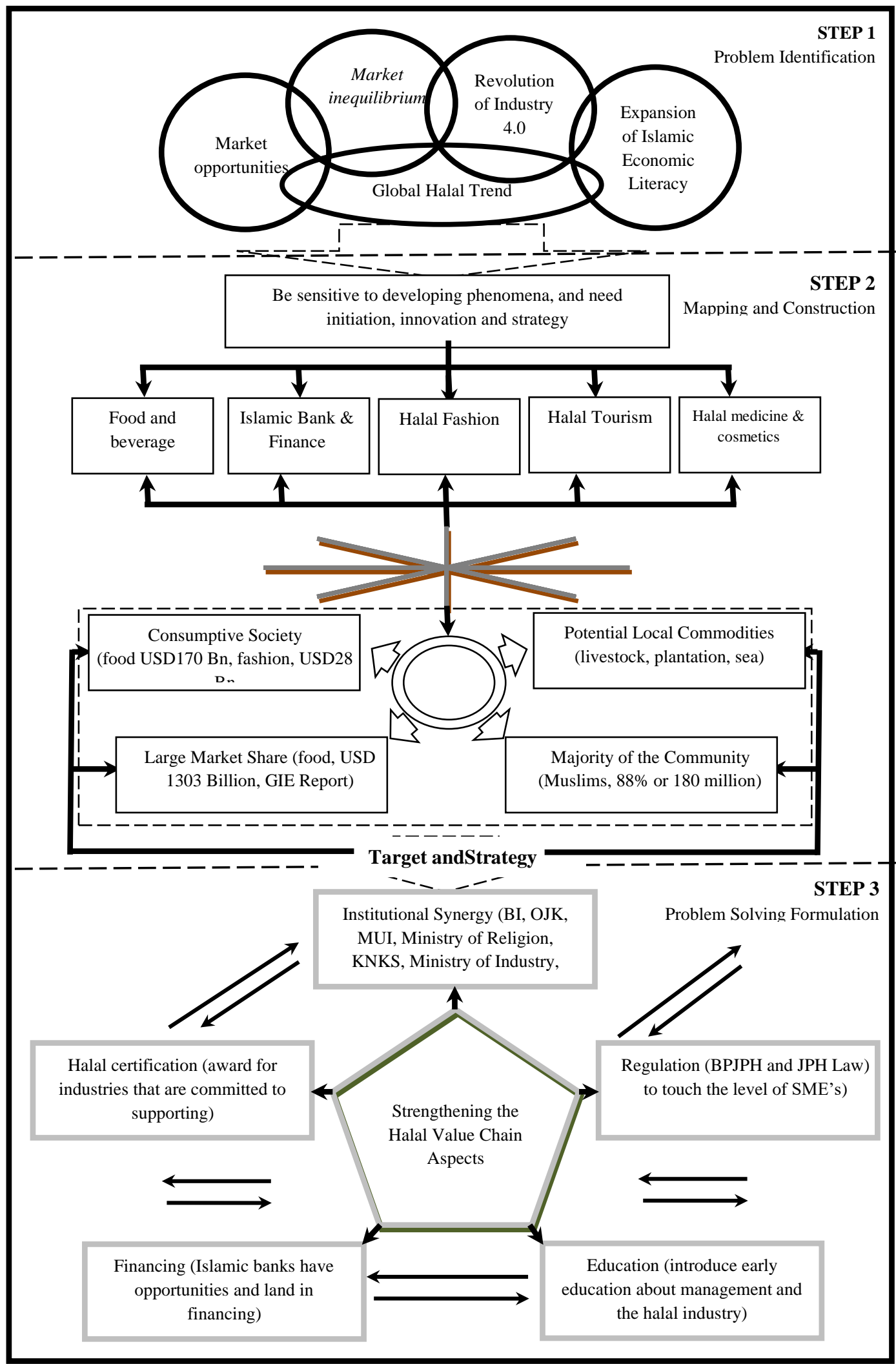

Figure 1. Model of Elements Synergy for the Strengthening Halal Industrial Productivity in Indonesia Source: compiled by author http://journal.unesa.ac.id/index.php/jie 
Following the results review and three discussion reviews which cover several aspects, it is necessary to simplification or simplifies the concept. The simplification form in this study is forgotten in the form of a measured and systematic model flowchart. The flowchart will be adjusted according to the discussion stage, which consists of 3 steps, namely problem identification, mapping and construction, and problem-solving formulation.

Based on Figure 1 above, the actual model also collaborates to some of the previous studies, following the synergy of science in question.

Table 1 . Halal industry studies that relevant to this study

\begin{tabular}{|c|c|c|c|}
\hline No & $\begin{array}{c}\text { Synergies of Halal } \\
\text { Industry in } \\
\text { Indonesia }\end{array}$ & $\begin{array}{l}\text { Past literature } \\
\text { Sources Data }\end{array}$ & Findings / Suggestions \\
\hline 1 & $\begin{array}{ll}\text { Synergy } & 1: \\
\text { Regulation } & \\
\text { Enhancement } & \end{array}$ & 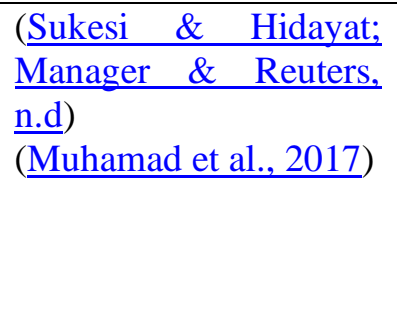 & $\begin{array}{l}\text { Cosmetic products are one of the } \\
\text { stimulators of Halal industries in } \\
\text { Indonesia. } \\
\text { Agro-industries are } \\
\text { potentialsectors ofHalal } \\
\quad \text { industries } \\
\text { Indonesia. }\end{array}$ \\
\hline 2 & $\begin{array}{l}\text { Synergy } \\
\text { Education } \\
\text { Enhancement }\end{array}$ & 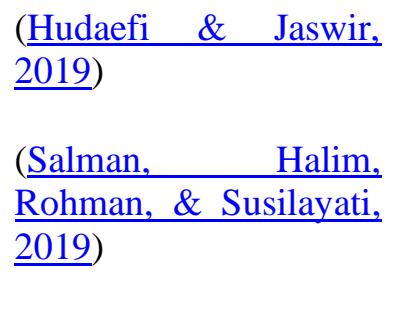 & $\begin{array}{l}\text { The existing } 18 \text { of Halal centres } \\
\text { in Indonesia are still not an } \\
\text { exhaustive medium of education. } \\
\text { Development of Halal Education } \\
\text { System in } \\
\text { Islamic Higher } \\
\text { EducationInstitutions }\end{array}$ \\
\hline 3 & $\begin{array}{l}\text { Synergy 3: Islamic } \\
\text { Banking } \\
\text { Enhancement }\end{array}$ & (Majid \& Agassi, 2017) & $\begin{array}{l}\text { Company Funding } \\
\text { Using Sharia Venture Capital }\end{array}$ \\
\hline
\end{tabular}

Source: compiled by author

Based on the explanation as to the table above, it can be described the potential division that can be done to support the strengthening of the halal industry in Indonesia. The following explanation is classified, as shown below.

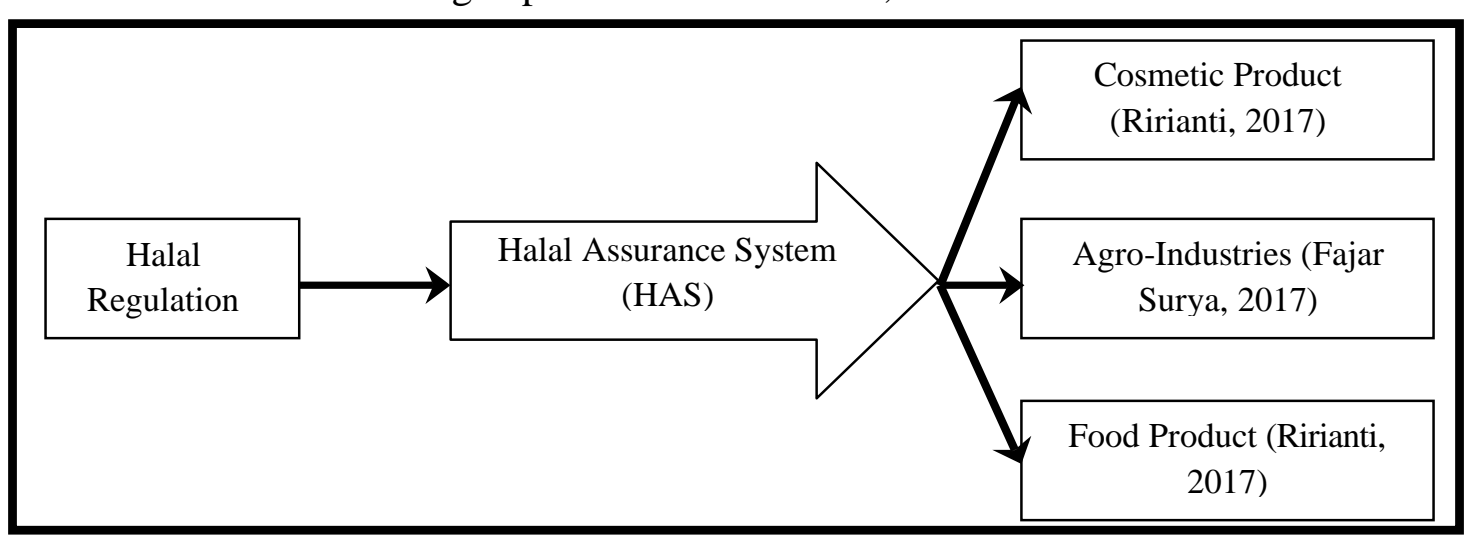

Figure 2. Model of Synergy 1 (Regulation Enhancement)

Source: compiled by author

Copyright (C) 2020, Al-Uqud: Journal of Islamic Economics http://journal.unesa.ac.id/index.php/jie 


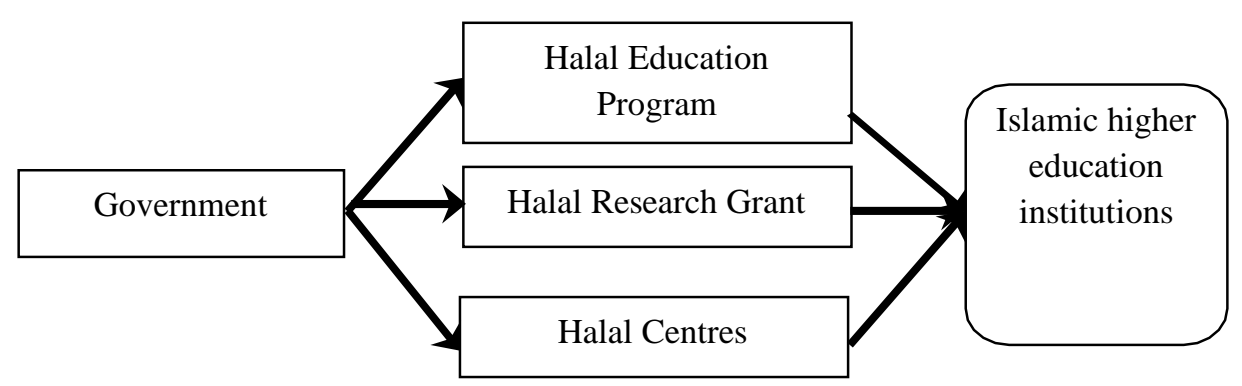

Figure 3.Model of Synergy 2 (Education Enhancement)

Source: compiled by author

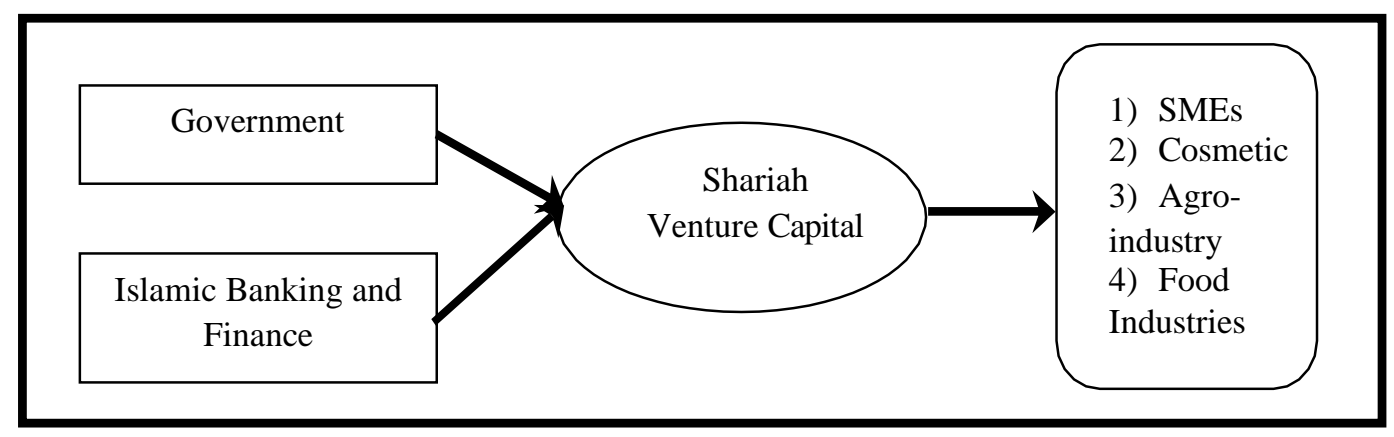

Figure 4. Model of Synergy 3 (Islamic Banking Enhancement)

Source: compiled by author

Based on the figure (1) of the element shellfish model in strengthening the halal industry in Indonesia, it can be divided into several sections. the part is halal assurance system, halal vocational education system, financial and banking improvement system. While the division of stages which has been tested and confirmed by many stakeholders, is expected to further strengthen the halal industry in Indonesia. Halal industry is not only as a market, but also producers and suppliers of halal raw materials.

\section{CONCLUSION}

This study concludes that Indonesia has great potential and market, but it turns out that the potential and market share has not been optimized independently. Nevertheless, instead of it becomes a relatively large consumer both in terms of halal food and drinks and halal fashion. The halal industry, like other industries, also requires the touch of many parties. The existence of demand, of course, must be balanced with offers. Commitments from various parties who want the realization of the halal industry must have become a substantial capital. However, that is not enough, because the support of the budget and financing and then the issuance of halal certification are expected to be able to improve the quality of Indonesia's increasingly creative and innovative economy.

Based on conclusions, the suggestion that can be delivered is the development of the halal industry must not only focus on the issue of certification but must also be directed at strengthening the role of the halal industry for an innovative national 
economy in the future. A vision is needed so that the halal industry not only makes Indonesia the biggest consumer because of its sizeable Muslim population, but Indonesia must be able to become a significant player in the global scene, or at least to be host in their own country. Hence, there is a need for integrated strategies and policies, which at least have already been initiated by KNKS together with other government agencies and should be continued. However, it is also important to realize that the export-oriented national halal industry needs real action in the form of promotion of Indonesian products aimed at emphasizing the halal and superiority of national products. Besides, the Indonesian Ulema Council (MUI) also needs to spearhead a halal standard which can later be approved globally so that Indonesian products are not hindered by differences in the "mazhab" of halal certification between countries, or in other words Indonesia can become a global halal standard reference.

\section{REFERENCES}

Ab Talib, M. S., Ai Chin, T., \& Fischer, J. (2017). Linking Halal food certification and business performance. British Food Journal, 119(7), 1606-1618. https://doi.org/10.1108/BFJ-01-2017-0019

Afifi, M., Wati, K., Syed, T., Najib, M., Omar, S., Ahmad, A., Alisa, A., Izhar, M., \& Kashim, M. (2014). Consumer Protection of Halal Products In Malaysia : A Literature Highlight. Procedia - Social and Behavioral Sciences, 121 (September 2012), 68-78. https://doi.org/10.1016/j.sbspro.2014.01.1109

Alam, N., Gupta, L., \& Shanmugam, B. (2017). Islamic finance: A practical perspective. In Islamic Finance: A Practical Perspective. https://doi.org/10.1007/978-3-319-66559-7

Ali, A., Xiaoling, G., Sherwani, M., \& Ali, A. (2017). Factors affecting Halal meat purchase intention: Evidence from international Muslim students in China. British Food Journal, 119(3), 527-541. https://doi.org/10.1108/BFJ-10-2016$\underline{0455}$

Antara, P. M., Musa, R., \& Hassan, F. (2016). Bridging Islamic Financial Literacy and Halal Literacy: The Way Forward in Halal Ecosystem. Procedia Economics and Finance, 37(16), 196-202. https://doi.org/10.1016/S2212$\underline{5671(16) 30113-7}$

Anwar, M. K., Fahrullah, A., \& Ridlwan, A. A. (2017). Sertifikasi Halal Sebagai Upaya Perlindungan Konsumen Muslim (Studi pada Lembaga Pengkajian Pangan Obat-obatan dan Kosmetika Majelis Ulama Indonesia Provinsi Jawa Timur). Prosiding Seminar Nasional PPM Universitas Negeri Surabaya, 538545.

Anwar, M. K., Fahrullah, A., \& Ridlwan, A. A. (2018). the Problems of Halal Certification. International Journal of Civil Engineering and Technology (IJCIET), 9(8), 1625-1632. http://www.iaeme.com/MasterAdmin/Journal_uploads/IJCIET/VOLUME_9 _ISSUE_8/IJCIET_09_08_162.pdf 
Ana Toni Roby Candra Yudha, Nasif Sidquee Pauzi, Rafidah binti Mohd

Azli: The Synergy Model for Strengthening the Productivity of Indonesian Halal Industry

Aprizal, A., Mirdhayati, I., \& Yendraliza, Y. (2019). Physical and Chemical Characteristic of Halal Gelatin Extracted from Buffalo Hide with Addition of Pineapple Rind at Different Ratio. Indonesian Journal of Halal Research, 1(1), 1-4. https://doi.org/10.15575/ijhar.v1i1.4109

Battour, M., Hakimian, F., \& Ismail, M. (2018). The perception of non-Muslim tourists towards halal tourism. 9(4), 823-840. https://doi.org/10.1108/JIMA07-2017-0072

Chitrakorn, K. (2015). Can Halal Cosmetics Outgrow Their Niche? BoF.

Davies, R. (2015). Industry 4.0. Digitalisation for productivity and growth. European Parliamentary Research Service.

Habibi, M. L., \& Yudha, A. T. R. C (2017). Membangun Integrated Takaful dan Wakaf Model dalam Upaya Meningkatkan Kemanfaatan Pemegang Polis. alUqud: Journal of Islamic Economics. 1(2), 139-155. http://dx.doi.org/10.26740/al-uqud.v1n2.p139-155

Haleem, A., \& Khan, M. I. (2017). Towards successful adoption of Halal logistics and its implications for the stakeholders. British Food Journal, 119(7), 15921605. https://doi.org/10.1108/BFJ-12-2016-0637

Hegnes, A. W. (2019). The map and the terroir: Adapting geographical boundaries for PDO and PGI in Norway. British Food Journal, 121(12), 3024-3042.

Hong, M., Sun, S., Beg, A. B. M. R., \& Zhou, Z. (2019). Determinants of halal purchasing behaviour: evidences from China. Journal of Islamic Marketing, 10(2), 410-425. https://doi.org/10.1108/JIMA-03-2018-0053

Hudaefi, F. A., \& Jaswir, I. (2019). Halal Governance in Indonesia: Theory, Current Practices, and Related Issues. Journal of Islamic Monetary Economics and Finance, 5(1), 89-116. https://doi.org/10.21098/jimf.v5i1.1049

Ishak, S., Awang, A. H., Hussain, M. Y., Ramli, Z., Md Sum, S., Saad, S., \& Abd Manaf, A. (2016). A study on the mediating role of halal perception: determinants and consequence reflections. Journal of Islamic Marketing, 7(3), 288-302. https://doi.org/10.1108/JIMA-02-2015-0010

Kamaruddin, R., Iberahim, H., \& Shabudin, A. (2012). Willingness to Pay for Halal Logistics: The lifestyle choice. 50(July), 722-729. https://doi.org/10.1016/j.sbspro.2012.08.075

Khasanah, N. N., Amalia, V., El Viera, B. V., \& Sawitri, A. (2019). Na-Alginate Utilization of Brown Algae (Sargassum sp.) as A Halal Edible Film Basic Materials. Indonesian Journal of Halal Research, 1(1), 9-13. https://doi.org/10.15575/ijhar.v1i1.4242

Kulsum, Y., Adawiyah, A., Shofwaturrohmani, F., \& Nurjanah, D. (2019). Pig Sample Handling in Research Laboratory Scale. Indonesian Journal of Halal Research, 1(1), 14-17. https://doi.org/10.15575/ijhar.v1i1.4091

Majid, R., \& Agassi, B. A. (2017). HASBLE Card: Innovation on Company Funding Using Shari'ah Venture Capital toward Halal Industry in Indonesia. Journal of Islamic Finance, 6(Special Issue), 242-256. https://doi.org/10.12816/0047352

Manager, B. S., \& Reuters, T. (n.d.). Digital islamic economy overview. 
Mohd Nawawi, M. S. A., Abu-Hussin, M. F., Faid, M. S., Pauzi, N., Man, S., \& Mohd Sabri, N. (2019). The emergence of halal food industry in non-Muslim countries: a case study of Thailand. Journal of Islamic Marketing. https://doi.org/10.1108/JIMA-05-2018-0082

Muhamad, N., Leong, V. S., \& Md Isa, N. (2017). Does the country of origin of a halal logo matter? The case of packaged food purchases. Review of International Business and Strategy, 27(4), 484-500. https://doi.org/10.1108/RIBS-06-2017-0049

Muhamed, A. A., Ab Rahman, M. N., Mohd Hamzah, F., Che Mohd Zain, C. R., \& Zailani, S. (2019). The impact of consumption value on consumer behaviour: A case study of halal-certified food supplies. British Food Journal, 121(11), 2951-2966. https://doi.org/10.1108/BFJ-10-2018-0692

Murti, T. W. (2017). Halal Life Style And Global Trade. The 7th International Seminar on Tropical Animal Production Contribution of Livestock Production on Food Sovereignty in Tropical Countries, 2, 33-39. https://journal.ugm.ac.id/istapproceeding/article/view/30115

Naeem, S., \& Ayyub, R. M. (2019). Systematic literature review of halal food. https://doi.org/10.1108/JIMA-09-2018-0163

Oseni, U. A., Ali, S. N., \& de Anca, C. (2019). Fintech in Islamic finance. In Fintech In Islamic Finance. https://doi.org/10.4324/9781351025584-4

Park, M., \& Jamaludin, M. A. (2018). A Framework of Halal Industry Support System in non-Muslim Country : A Focus on South Korea. Journal of Halal Industry and Service, 1(1), 1-14.

Rahman, F. K. (2017). Maqashid Al-Shari 'ah -based performance measurement for the halal industry. 33(3), 357-370. https://doi.org/10.1108/H-03-20170054

Reuters, T. (2018). State of Global Islamic Economy Report 2018/19. In Dubai International Financial Centre.

Ryandono, M. N. H., \& Ridlwan, A. A. (2020). Solution for Islamic Banks Exploitation: A Criticism of Fixed-Yields Based Financing in Indonesia. AlUqud: Journal of Islamic Economics, 4(1), 48-68. http://dx.doi.org/10.26740/al-uqud.v4n1.p48-68

Salman, A. M., Halim, A., Rohman, N., \& Susilayati, M. (2019). "Halal" As a Competitive Distinction for Islamic Higher Education in Preparing Muslim Millenials. Indonesian Journal of Islamic Literature and Muslim Society, 3(2), 111. https://doi.org/10.22515/islimus.v3i2.1922

Salman, A. S. (2018). Non-Muslims ' acceptance of imported products with halal logo. 9(1), 191-203. https://doi.org/10.1108/JIMA-02-2016-0009

Satya, V. E. (2018). Strategi Indonesia Menghadapi Industri 4.0. Kajian Singkat Terhadap Isu Aktual Dan Strategis.

Shaari, M. N. (2018). Revolusi industri 4.0: Suatu Pengenalan. Abatan Perdana Menteri.

Sukesi, \& Hidayat, W. G. P. (2019). Managing the Halal industry and the purchase intention of Indonesian Muslims the case of Wardah cosmetics. Journal of Indonesian Islam, 13(1), 200-229. https://doi.org/10.15642/JIIS.2019.13.1.200-229 
Ana Toni Roby Candra Yudha, Nasif Sidquee Pauzi, Rafidah binti Mohd

Azli: The Synergy Model for Strengthening the Productivity of Indonesian Halal Industry

Swidi, A., Wie, C., Hassan, M. G., Hosam, A. A., \& Kassim, A. W. K. (2010). The Mainstream Cosmetics Industry in Malaysia And The Emergence, Growth, And Prospects of Halal Cosmetics. Proc. the Third International Conference on International Studies.

Takeshita, S. (2019). Halal certification or ingredient disclosure: A comparative analysis of serving food in Japanese tourist destinations. Journal of Islamic Marketing, 03417(15). https://doi.org/10.1108/JIMA-07-2018-0129

Tan, K. H. (2017). The impact of external integration on halal food integrity. 2(April), 186-199. https://doi.org/10.1108/SCM-05-2016-0171

Thomson Reuters and Dinar Standard. (2018). State of the Global Islamic Economy Report 2019/20. Dubai International Financial Centre.

Tieman, M. (2011). The application of Halal in supply chain management : indepth interviews. https://doi.org/10.1108/17590831111139893

Tieman, M. (2019). Measuring corporate halal reputation A corporate halal reputation index and. https://doi.org/10.1108/JIMA-05-2018-0095

Tieman, M., \& Ghazali, M. C. (2012). Principles in halal supply chain management. 3(3), 217-243. https://doi.org/10.1108/17590831211259727

Toni, A. (2020). Profesionalisme dosen luar biasa (DLB) pada era milenial di uin sunan ampel surabaya: sebuah studi analisis konten. 2, 77-86.

Wahyu, M., \& Sheikh, F. (2016). Non-Muslim Consumers' Halal Food Product Acceptance Model. Procedia Economics and Finance, 37(16), 276-283. https://doi.org/10.1016/S2212-5671(16)30125-3

Wingett, F., \& Turnbull, S. (2020). Halal holidays : exploring expectations of Muslim-friendly holidays. https://doi.org/10.1108/JIMA-01-2016-0002

Yudha, A. T. R. C., \& Dusturiya, N. (2018). Model Pengembangan Kewirausahaan Sosial Berbasis Mahasiswa pada Lembaga Amil Zakat. El-Qist, 8(1), 16181637.

Yudha, A. T. R. C., Ryandono, M. N. H., Rijal, A., \& Wijayanti, I. (2020). Financing model to develop local commodity business of East Java in Maqashid Syariah perspective. Test Engineering and Management, 83(3590), 3590-3595.

Zaki, I., Widiastuti, T., Yudha, A. T. R. C., Wijayanti, I., \& Mi'raj, D. A. (2020). Implementation of Islamic entrepreneurial culture in Islamic boarding schools. International Journal of Innovation, Creativity and Change, 11(11), 452-469. 